\title{
Guidelines of the Polish Ophthalmological Society on how to deal with ophthalmic patients during the COVID-19 epidemic*
}

\author{
Jacek P. Szaflik' ${ }^{1}$, Marcin Stopa ${ }^{2}$, Andrzej Horban ${ }^{3}$, Joanna Przybek-Skrzypecka' ${ }^{1}$, Alina Bakunowicz-tazarczyk ${ }^{4}$, \\ Dariusz Dobrowolski ${ }^{5,6,7}$, Iwona Grabska-Liberek ${ }^{8}$, Justyna Izdebska ${ }^{1}$, Jakub Kałużny ${ }^{9}$, Jerzy Mackiewicz ${ }^{10,11}$, \\ Marta Misiuk-Hojło" ${ }^{12}$, Ewa Mrukwa-Kominek ${ }^{13}$, Bożena Romanowska-Dixon ${ }^{14}$ \\ 'Department of Ophthalmology, Medical University of Warsaw, SPKSO Ophthalmic University Hospital, Warsaw, Poland \\ 2Department of Ophthalmology, Chair of Ophthalmology and Optometry, Heliodor Swiecicki University Hospital, Poznan University \\ of Medical Sciences, Poznan, Poland \\ ${ }^{3}$ Clinic of Infectious Diseases in Adults, Medical University of Warsaw, Warsaw, Poland \\ ${ }^{4}$ Department of Pediatric Ophthalmology with Strabismus Treatment Centre, Medical University of Bialystok, Bialystok, Poland \\ ${ }^{5}$ Chair and Clinical Department of Ophthalmology, School of Medicine, Dentistry Division in Zabrze, Medical University of Silesia, Poland \\ ${ }^{6}$ Department of Ophthalmology, District Railway Hospital in Katowice, Poland \\ ${ }^{7}$ Department of Ophthalmology with Pediatric Unit, St Barbara $5^{\text {th }}$ Regional Hospital in Sosnowiec, Poland \\ ${ }^{8}$ Ophthalmology Department, Centre of Postgraduate Medical Education, Warsaw, Poland \\ ${ }^{9}$ Department of Sense Organ Research, Collegium Medicum in Bydgoszcz, Nicolaus Copernicus University in Toruń, Poland \\ ${ }^{10}$ Department of Retina and Vitreous Humour Surgery, Medical University of Lublin, Lublin, Poland \\ ${ }^{11}$ Independent Public Teaching Hospital No. 1 in Lublin, Poland \\ ${ }^{12}$ Department and Clinic of Ophthalmology, Wroclaw Medical University, Wroclaw, Poland \\ ${ }^{13}$ Department of Ophthalmology, Medical University of Silesia, Katowice, Poland \\ ${ }^{14}$ Department of Ophthalmology and Ocular Oncology, University Hospital in Krakow, Poland
}

\section{ABSTRACT}

SARS-CoV-2 is a coronavirus that causes COVID-19 (coronavirus disease 2019). In March 2020 the World Health Organization (WHO) declared a coronavirus pandemic. Individuals employed at ophthalmic departments and clinics are especially exposed to transmission of the virus due to the specific nature of an ophthalmic examination. The Polish Ophthalmological Society presents Guidelines that recommend implementation of an appropriate level of safety measures in ophthalmic care provided to patients.

KEY WORDS: COVID-19, SARS-CoV-2, ophthalmological examination.

\section{GENERAL INFORMATION}

SARS-CoV-2 is a coronavirus that causes COVID-19 disease (coronavirus disease 2019). The viral particle contains single-stranded RNA composed of approximately 30 thousand nucleotides, and has a diameter of 60-140 nm, which makes it one of the largest RNA viruses [1]. The virus spreads through droplets. The incubation period is 1-14 days (approx. 5-7 days from exposure to symptom appearance) [2]. Its presence may be detected in secretions from the nose, throat, blood, sputum, stool, and tears. The first reports mentioning infections with the virus came from Wuhan in China (November 2019) [3]. Symptoms of the infection include, first and foremost, cough and fever (Table I). The virus has a predilection for the re-

\footnotetext{
${ }^{*}$ Guidelines of scientific societies and associations (including the Polish Ophthalmological Society) do not constitute binding laws and do not determine the only correct procedures; they are only an opinion of a group of experts from a given field. The opinion reflects the current state of knowledge based on available scientific research results.

The guidelines do not exempt healthcare workers from personal liability with regard to making the correct decisions for individual patients.

Personal responsibility for the used therapeutic methods rests with all individuals who practise medicine. It should be based on thorough knowledge and practical skills, while observing necessary safety measures with regard to oneself and the patient.

Readers of this paper are obliged to make themselves familiar with current information on the presented treatments and pharmacotherapies with special attention paid to manufacturers' information on doses, time, and administration as well as side effects of the used drugs.

The publishers and editors of the paper shall not be responsible for any damages that could in any way be connected to the contents of this paper.
} 
Table I. COVID-19 symptoms and their prevalence (number of patients included in the study $n=55,923$ ) [9]

\begin{tabular}{|l|c|}
\hline Symptoms & $\begin{array}{c}\text { Percentage of patients } \\
\text { with the symptom }\end{array}$ \\
\hline Fever & $87.9 \%$ \\
Dry cough & $67.7 \%$ \\
Fatigue & $38.1 \%$ \\
Expectoration (with blood) & $33.4 \%(0.9 \%)$ \\
Dyspnoea & $18.6 \%$ \\
Sore throat & $13.9 \%$ \\
Headache & $13.6 \%$ \\
Muscle and joint pain & $14.8 \%$ \\
Shivers & $11.4 \%$ \\
Nausea and emesis & $5 \%$ \\
Nasal congestion & $4.8 \%$ \\
Diarrhoea & $3.7 \%$ \\
Conjunctivitis / chemosis & $0.8 \%$ \\
\hline
\end{tabular}

spiratory epithelium, and causes severe pneumonia that may require mechanical ventilation. Laboratory tests confirm leucopoenia and lymphopenia [4]. Mortality and severity of the disease course increase with age. Zhou et al. reported a higher prevalence of concomitant diseases such as arterial hypertension $(30 \%)$, diabetes (19\%), coronary arterial disease (8\%), and chronic obstructive pulmonary disease (COPD) (3\%) in patients requiring hospitalization due to COVID-19 in Wuhan [5].

On 11 March 2020, the World Health Organization (WHO) announced a coronavirus pandemic [6]. As of today, over 271 thousand patient cases and over 11 thousand deaths have been confirmed due to COVID-19 (data as of 21 March 2020) [7]. COVID-19 should be suspected in an individual who has at least one of the following symptoms: fever $>38^{\circ} \mathrm{C}$, cough or shortness of breath $\left(\mathrm{SaO}_{2}<95 \%\right.$, number of breaths $\left.>20 / \mathrm{min}\right)$, and who meets one of the following additional criteria:
- during the last 14 days has travelled or been to a country/ geographical region in which it has been noted that the virus is spreading;

- during the last 14 days has had close contact with a person who has a possible or confirmed case of COVID-19 disease;

- a severe (requiring hospitalization) course of a lower respiratory tract infection is confirmed with lack of another aetiology that could explain the clinical presentation.

So far, neither effective causal treatment nor vaccines preventing the disease have been developed. Only symptomatic treatment is available, and therefore preventive actions are of the essence [8].

\section{OPHTHALMIC SYMPTOMS}

Ophthalmic symptoms that may appear during the course of SARS-CoV-2 infection result from the presence of the virus in the tear film and conjunctival sac secretions [10]. So far, only cases of conjunctivitis and chemosis caused by SARS-CoV-2 have been described.

\section{PROPHYLAXIS}

Employees of ophthalmic departments and units are especially exposed to transmission of the virus due to the specific nature of an ophthalmic examination (the distance between the patient's face and the physician in the slit lamp is $<1.8 \mathrm{~m}$, which is considered a high risk factor for transmission of the virus).

Available forms of personal protection include:

- disposable gowns,

- masks: surgical, FFP2, FFP3,

- face shields, goggles,

- gloves [11].

It should be remembered to regularly disinfect one's hands, the slit lamp, and objects that have contact with patients. Rec-

Table Il. Classification of dealing with a patient who requires ophthalmological care depending on the risk of SARS-CoV-2 infection (on the basis of American Academy of Ophthalmology [AA0] guidelines: https://www.aao.org/headline/alert-important-coronavirus-context)

\begin{tabular}{|c|c|}
\hline $\begin{array}{l}\text { Urgent ophthalmology } \\
\text { appointment for a patient } \\
\text { with no respiratory illness } \\
\text { symptoms, no fever, and } \\
\text { no COVID-19 risk factors }\end{array}$ & $\begin{array}{l}\text { - standard precautions (hand hygiene, cleaning and disinfecting environmental surfaces, cough etiquette) } \\
\text { - added precaution of not speaking during slit-lamp examinations } \\
\text { - usage of a slit-lamp breath shield } \\
\text { - mask, gloves, goggles/face shields, and protective clothing (PPE) are not routinely required for a patient or physician } \\
\text { - if during the examination the case turns out to be non-urgent, postponement of treatment may be considered }\end{array}$ \\
\hline $\begin{array}{l}\text { Urgent ophthalmic } \\
\text { problem in a patient } \\
\text { with respiratory illness } \\
\text { symptoms, but no fever } \\
\text { or other COVID-19 risk } \\
\text { factor }\end{array}$ & $\begin{array}{l}\text { - the patient can be seen in the ophthalmic clinic } \\
\text { - the examination should not take too long } \\
\text { - the patient should wear a surgical mask } \\
\text { - the treating ophthalmologist and health care personnel require surgical masks } \\
\text { - mask (FFP2, FFP3), gloves, goggles/face shields, and protective clothing are recommended; however, due to possible } \\
\text { shortages of personal protective equipment as the epidemic expands, universal usage of it for all patient encounters } \\
\text { is not appropriate; the decision should be made on a case-by-case basis depending on the situation; routine usage is } \\
\text { not appropriate considering the broader context }\end{array}$ \\
\hline $\begin{array}{l}\text { Patient with high } \\
\text { probability of COVID-19 } \\
\text { or documented } \\
\text { SARS-CoV-2 infection }\end{array}$ & $\begin{array}{l}\text { - the patient should be sent to the ER of the infectious disease hospital } \\
\text { - if the patient has an urgent eye problem based on screening questions, optimally, the assistance should be provided } \\
\text { within the infectious disease hospital with the use of masks (FFP2, FFP3), gloves, goggles/face shield, and protective } \\
\text { clothing } \\
\text { - if there is no possibility to transfer the patient, ophthalmic help may be provided with the use of masks (FFP2, FFP3), } \\
\text { gloves, goggles/face shield, protective clothing, and then a decision should be made whether the patient should be } \\
\text { transferred to a department indicated for treating SARS-CoV-2-patients within the hospital }\end{array}$ \\
\hline
\end{tabular}


ommended disinfectants include a $70 \%$ solution of ethyl alcohol, $0.1 \%$ sodium hypochlorite, $5 \%$ bleaching agent, and hospital antiseptic viricidal agents [12]. Every piece of ophthalmic equipment should be disinfected before and after contact with every single patient (slit lamp, Goldmann applanation tonometer, three-mirror lens).

Due to the pandemic, we recommend introducing a threestage path of taking precautions while providing ophthalmic care for patients [13]:

1. Level one includes:

a) limiting routine appointments and elective procedures (excluding conditions that pose a risk of irreversible vision worsening); postponing planned ophthalmic procedures; introducing telemedical advice services, and electronic prescriptions;

b) introducing an epidemiological questionnaire (1. Contact with a person who has COVID-19 symptoms or who is infected with SARS-CoV-2; 2 . Staying in areas with a high percentage of infections during the last 14 days; 3. Symptoms: body temperature $>38^{\circ} \mathrm{C}$, cough, shortness of breath) that is the basis of triage of patients who report to the ophthalmologist's;

c) discontinuation of procedures that produce aerosol, e.g. noncontact tonometry (air puff), endoscopic tear duct drainage, general anaesthesia;

d) training for the medical personnel on how to minimize the risk of infection in the face of the pandemic.

2. Level two includes:

a) usage of slit-lamp barriers (breath shields) that separate patients from physicians. It decreases the risk of ophthalmic personnel aspiring the air exhaled by the patient that potentially contains SARS-CoV-2 particles; b) frequent disinfections of hands and equipment in the ophthalmologist's room;

c) daily measurements of body temperature; reporting the following symptoms to the employer: shortness of breath, cough, fever, emesis, and diarrhoea.

3. Level three includes:

a) all employees of ophthalmic facilities and patients are to wear masks;

b) strict hand hygiene;

c) usage of proper personal protective equipment (PPE) by the medical personnel;

d) patients should keep a minimum 1-metre distance from each other (in the waiting room).

Every patient reporting to the ophthalmic clinic/hospital should have their body temperature taken and be asked to complete a short questionnaire (1. Contact with a person who has COVID-19 symptoms or who is infected with SARS-CoV-2; 2. Staying in areas with a high percentage of infections during the last 14 days; 3 . Symptoms: body temperature $>38^{\circ} \mathrm{C}$, cough, shortness of breath) that constitutes the basis for taking special preventive measures. Table II shows necessary preventive measures that should be taken by medical personnel of the ophthalmic clinic/hospital depending on the clinical and epidemiological situation [2].

In cases where it is necessary to transfer a patient to an infectious disease hospital, or an infectious disease hospital where only patients with coronavirus infections are treated, the nearest facilities can be found at the following website: https:// www.gov.pl/web/koronawirus/lista-szpitali

\section{DISCLOSURE}

The authors declare no conflict of interest.

\section{References}

1. Zhu N, Zhang D, Wang W, et al. A novel coronavirus from patients with pneumonia in China, 2019. N Engl J Med 2020, 382: 727-733.

2. https://www.aao.org/headline/alert-important-coronavirus-context

3. https://www.scmp.com/news/china/society/article/3074991/coronavirus-chinas-first-confirmed-covid-19-case-traced-back (accessed: $21.03 .2020,17.23)$

4. Hui DS, I Azhar E, Madani TA, et al. The continuing 2019-nCoV epidemic threat of novel coronaviruses to global health - the latest 2019 novel coronavirus outbreak in Wuhan, China. Int J Infect Dis 2020; 91: 264-266.

5. Zhou F, Yu T, Du R, et al. Clinical course and risk factors for mortality of adult inpatients with COVID-19 in Wuhan, China: a retrospective cohort study. Lancet 2020; pii: S0140-6736(20)30566-3. doi: 10.1016/S0140-6736(20)30566-3 [Epub ahead of print].

6. World Health Organization (WHO). BREAKING „We have therefore made the assessment that COVID19 can be characterized as a pandemic", @WH0, 11 marca 2020 (accessed: 11.03.2020).

7. ECDChttps://www.ecdc.europa.eu/en/all-topics-z/coronavirus/threats-and-outbreaks/covid-19/preparedness-and-response-covid-19 (accessed: 01.04.2020)

8. https://www.gov.pl/web/koronawirus

9. Report of the WHO-China joint mission on coronavirus disease 2019 (COVID-19). World Health Organization 2020.

10. Xia J, Tong J, Liu M, et al. Evaluation of coronavirus in tears and conjunctival secretions of patients with SARS-CoV-2 infection. J Med Virol 2020, jmv.25725, doi: 10.1002/jmv.25725 (accessed: 11.03.2020).

11. Rymer W, Wroczyńska A, Matkowska-Kocjan A. Jakie środki ochrony przed wirusem SARS-CoV-2 zastosować w gabinecie okulistycznym? mp.pl: https://www.mp.pl/covid19/ekspertcovid2019/229593,jakie-srodki-ochrony-przed-wirusem-sars-cov-2-zastosowacw-gabinecie-okulistycznym

12. https://www.ecdc.europa.eu/sites/default/files/documents/COVID-19-infection-prevention-and-control-healthcare-settingsmarch-2020.pdf

13. Lai THT, Tang EWH, Chau SKY, et al. Stepping up infection control measures in ophthalmology during the novel coronavirus outbreak: an experience from Hong Kong. Graefes Arch Clin Exp Ophthalmol 2020; doi: 10.1007/s00417-020-04641-8 [Epub ahead of print].

The guidelines were approved by the Management Board of the Polish Ophthalmological Society on 23 March 2020. 